\title{
フラットパネルディスプレイ（FPD）の エルゴノミクス課題*
}

この報告は，本学会に新しく設置されることになっ た「FPD（フラットパネルディスプレイ）の人間工学 ガイドライン検討委員会」が活動を始めるにあたり, FPD 人間工学の今日的課題について専門家諸氏が議 論した内容を, 視覚エルゴノミクス研究部会としてま とめたものである.

\section{FPD 利用の人間エ学ガイドライン の検討}

\section{産業医学総合研究所 斉藤 進}

液晶ディスプレイに代表されるフラットパネルディ スプレイ（FPD）の導入が，オフィスや家庭で急速に 進展している。これまではCRT が利用されてきた VDT 職場でも, FPD を搭載したノート型 PC が普通 にみられるようになってきた。実際，日本電子機械工 業会による 1996 年度の液晶ディスプレイの国内生産 高の見通しは，すでに金額ベースでCRT と並んでい る.

日本人間工学会では 1996 年 10 月に開催した第 62 回理事会において，新しく「FPD（フラットパネルデ イスプレイ）の人間工学ガイドライン検討委員会」を 設置した。筆者が代表として, 委員会設置議案を提出 した. FPD は CRT に比べ, 少ない電力消費や机上ス ペースなど多くの優れた特徵を持つが，一方では視覚 疲労や作業姿勢などの点からは多くの問題のあること が指摘されている.そこで, CRT とはその形態, 機 構, 光学上の特性が異なる FPD に対し, 固有の利用上 の人間工学ガイドラインが必要となると考えられたか らである. 委員会の活動目標は, FPD 利用の人間工学 ガイドラインを社会へ提案するとともに, FPD 機器の 開発者が利用者ニーズを理解し，ヒトを向いた設計指 針（Human-Centred Design）を考える際にこのガイ

* 1996 年 11 月 12 日受付

**視覚エルゴノミクス研究部会部会長 斉藤 進

\section{視覚エルゴノミクス研究部会**}

ドラインを役立ててもらうことである.

しかし国内外の人間工学に関連する諸学会の研究活 動の現状をみた場合, FPD 利用の人間工学に関する知 見は少なく, この方面の研究は活発に行われていると はいえない．視覚エルゴノミクス研究部会では，FPD のヒューマン・ファクターを主題としたシンポジウム をこれまで数回にわたり主催してきた（1995 年度 成 蹊大学, 1994 年度 日本アイ・ビー・エム(侏), 1993 年 度第 2 回日本人間工学会システム関連部会連合大 会).また 1996 年 8 月には FPD をめぐる円卓会議を 開催し,この分野の現状を把握するとともに今後の展 開を議論した。そこで以下に，これらのシンポジウム や円卓会議に積極的に参加していただいた専門家の 方々に, FPD 人間工学の今日的課題と今後の望まれる 方向についての考え方を簡単にまとめてもらうことに した。これらの方々の多くは，上に述べた「FPD の人 間工学ガイドライン検討委員会」の中心的な委員でも あり，今後の指針作成に大きな役割を果たすことが期 待されている.

\section{2. 利用実態を考慮した多元的実験に基 づく開発指針の必要性}

\section{成蹊大学工学部 淕田 悟}

ユーザ主導型の生産体制への移行は, フラットパネ ルディスプレイ（FPD）産業においても例外ではな い. FPD メーカーにとっては, ユーザの視覚特性と使 用実態に即した製品を供給できるかどうかが鍵となる。 言い換えれば，エルゴノミクス上の要求を部材のレべ ルまで製造の流れを遡って, いかに還元できるかが決 め手となる. しかし, 部材を調達し, デバイスとして 組み上げ，ノートパソコンやカーナビゲーションなど の最終製品に組み込む過程をみると，新しいテクノロ ジーを駆使した製品がリリースされる前にエルゴノミ クスが介在する余地は少ない。それは, FPD が過当競 
争とコストリダクションの圧力下にあるからだけでは ない．部材を集めて最終製品にする一方的な流れの中 では，ユーザの評価を予測する手立てがほとんどない という現実がある。ささら，最終製品の性能は, 部材 に依存することが多い，ところが，ほとんどの場合， デバイスメーカーと部材メーカーは, まったく別会社 である.

そこで, 部材メーカーまで一貫して利用できる開発 指針が必要となる，その鍵を握るのが測定・評価方法 である，現状では，既製の測定器により，何らかの物 理的あるいは心理物理的測定值を得ている. その測定 值は必ずしも最終製品におけるユーザの評価に即した ものではない，確かに，物理特性だけでことが済む半 導体はそれでもよかったのであろう。

結局，エルゴノミクスを考慮した製品開発を可能に するのは, 使用実態を考慮した多元的な実験結果に基 づく開発指針の設定である．ただし，この開発指針は 製品から部材に対して適用可能で，かつ, 開発技術者 が容易に利用できるような形にしなくてはならない. おそらく，利用実態を考慮した測定方法とその測定値 からユーザの評価を予測できる評価式の提示というス タイルが最も効果的であろう. 使用実態とユーザの多 様性を考えると一つの評価式を提示するのにも幾多の 実験が必要となる，もとより，ディスプレイのエルゴ ノミクスとは，“人にやさしい”とか“目にやさしい” といった軽薄なことばでお茶をにごすことではなく， “技術力の行使の仕方”を徹底して追究していくことで あろう。もちろんこれはディスプレイに限ったことで はない.

\section{FPD のデバイスレベルとシステム レベルにおけるエルゴノミクス課題}

\section{日本アイ・ビー・エム侏人間工学 吉武良治}

FPD のエルゴノミクスの問題は, 製品の開発者/研 究者だけではなく, 製品やシステムの購入者, 仕事上 の管理者そして直接の利用者自身も, 正しく理解し, 一緒に考えてゆく必要がある。それぞれの立場におい て適切な配慮がなされ, うまくコミュニケーションで きれば，最適な作業環境，作業条件を実現できるはず である、しかしながら，このコミュニケーションがう まくいっていない場合が多い，FPDに関していえば, ディスプレイデバイス（表示装置のエルゴノミクス） の問題と FPD を搭載したシステム（たとえばノート 型 PC)の問題が混乱している場合がある。ここでは開 発者/研究者, 仕事の管理者や利用者が, FPD のエル
ゴノミクスの問題をできるだけ正しく理解し，共通認 識できることを目的とし，課題の対象をデバイスレ心゙ ルとシステムレベルに分け，それぞれの視点でのエル ゴノミクス上の現状および考慮点について概観する。

まずFPD のディスプレイデバイスレベルにおいて 考える.ディスプレイデバイスのエルゴノミクス上の 第一の課題は表示品質（画質）である. 1980 年代後半 に携帯型 PCのディスプレイとして利用された初期の FPD は，そのほとんどがSTN LCD であり，CRT に 比較してその画質は明らかに劣っていた。しかしなが ら FPD 技術の急速な発展によって, 最近では高画質 の TFT 型 LCD が広く携帯型 PC に搭載されるよう になり，またモニター仕様の LCD も出揃い,すでに画 質としては CRT と遜色のないレベルまできていると いってよい1). 現在の LCD は見る角度によって見え方 が変わる点はまだ CRT に劣っている場合が多いが, 画像のくっきりさやひずみのない表示など優れている 点も多い. LCD と CRT の画質の違いについては, 現 在のところ一概にどちらがよい, 悪いということは難 しい.それぞれの技術の範疇で，画質のよいものと徳 いもののレベル差のほうがかなり大きいと理解したほ うがよいと思われる。ここでエルゴノミクス上の考慮 点は, 用途に応じて必要なディスプレイを使い分ける ことであろう。一般に最新でかつ高価な高性能ディス プレイほどエルゴノミクス上の性能も優れているが, すべての用途にそのような高性能ディスプレイが必要 というわけではない. 表示内容, 利用場所, 利用時間 などによって使い分けることになろう。誌面の都合上, 細かい性能要求については触れないが, 画質の善し悪 しを客観的に判断する基準として，エルゴノミクス規 格への適合，不適合がある。規格としては，VDTを用 いたオフィス作業についてのエルゴノミクス要求をま とめた ISO 9241 シリーズやFPDを対象とした ISO 13406 シリーズがある. 表示装置のエルゴノミクス規

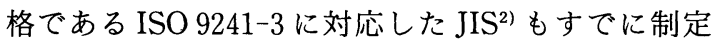
されており，ディスプレイデバイスのエルゴノミクス を考える際には参考になると思われる。

次にシステムレベルにおいて考える．まず FPD の 出現によって可能になった代表的なシステムであるノ ート型 PC を例にとる. FPD のエルゴノミクス課題を 考える場合にノート型 PCを思い浮かべる人も多いで あろう.しかしながら,ノート型 PCのエルゴノミクス 課題は, FPD だけでなくもっと広く考える必要があ る.元来ノート型 PC は, 携帯性を重視した設計になっ ているため,さまざまな制約がある. 通常ディスプレ イとキーボードが一体となっており，オフィス外での 膝上（ラップトップ）での利用も可能で非常に便利で 
ある.しかしながら，一方ではそれをオフィスで利用 する場合は，視距離がある範囲に規定され，姿勢が拘 束されやすい.ノート型 PC はその作業姿勢が拘束さ れやすいことから，オフィスでの長時間にわたる連続 利用（入力オペレー夕などによる利用）には向いてい ない場合が多い.また大きさの制約や低消費電力化な どによって,デスクトップ型 PC に比べて, 仕様が抑え られている場合があるため, タスクによっては使い勝 手がよくない場合がある。通常キーボードは狭い面積 に押し込められ，ディスプレイの大きさも基本的には 本体よりも小さくならざるを得ない.これらの制約を， 特に会社においては購入者, 管理者が理解した上で導 入すべきである.オフィスでの PC の利用時間がそれ ほど長くなく, 移動が必要な場合にはノート型 PC は 非常に有効であるが, 単純に省スペースのためだけに ノート型 PC を選択することはエルゴノミクス上の問 題を引き起こす可能性がある。これらは FPDによる 問題ではなく, FPD を搭載したノート型 PC の問題で ある。もしスペースを節約したいのであれば，分離型 でモニター仕様の LCD もすでに多くのメーカーから 製品化されているため, それらを選択することがエル ゴノミクス上の改善となるであろう。すでにノート型 PC を使っている利用者の立場から考えると, 使い方 の工夫によってエルゴノミクス上の課題が改善できる こともある．たとえば大きさの制約からキーボードの 高さがかなり高いノート型 PC があるが, この場合に は利用時には椅子を高くするだけでかなり効果がある. またキーボードが高くかつパームレストがついていな いノート型 PC の場合は, 手前に本などを置いて自分 なりに楽に手首を休ませることができるスペースを作 ることによって利用環境が改善される. またノート型 PC のディスプレイで表示解像度や色数に制限がある 場合は，外付けのディスプレイを接続することも状況 によっては使い勝手の向上になる. 同時にキーボード も外付けにすれば, デスクトップ型 PC とほほ同等の 作業環境を満たすこともできる，このように利用目的 によって使い方を工夫することも可能である.

FPD を用いたシステムはノート型 PCだけではな い. 今後も FPDによって実現される新しいテーマの エルゴノミクス課題は, 商品の数だけ生まれてくると 思われる.たとえばペン入力のタブレットなどは FPD を利用した代表的なシステムであるが，その書き味な どは重要な課題である. 今後は携帯情報端末や大型テ レビジョンなど, FPD はますます多くの人に身近なも のとなってくる.開発者/研究者, 購入者, 管理者そ して利用者がうまくコミュニケーションし，それぞれ の立場で FPD のエルゴノミクスを考慮することによ
ってよりよい利用環境を実現することができると考え る.

\section{参考文献}

1）日経 CG：16 インチにまで進歩した高品質カラ 一液晶ディスプレイ, 1996 年 8 月号, pp. $120 \sim 127,1996$.

2）JIS Z 8513-1994: 人間工学一視覚表示装置を 用いるオフィス作業一視覚表示装置の要求事項, 日本規格協会発行, 1994 .

\section{4. ノート型パソコンの使い勝手と 問題点}

\section{日本大学生産工学部 堀江良典}

VDTについての人間工学的な国際規格として現在 検討が加えられ，間もなく発効するであろう ISO 9241 シリーズの中に，ユーザビリティを扱っているパート 11 がある.ここではユーザビリティを《ある環境にお いて, 特定のユーザが特定の目標（ゴール）を達成す るためにプロダクトを効果的, 効率的, 満足に使用す ることのできる度合い》と定義している ${ }^{1)}$. FPD を用い た製品の代表であるノート型パソコンの使い勝手につ いて, 効果的, 効率的, 満足に使用できる度合いの要 因を探ると,CRT を用いた従来のデスクトップ型パソ コンとは異なる問題点が明らかとなる。

ノート型を特徵づける携帯性, 可搬性を左右するサ イズについて, 市販されている各社の標準的なノート 型とデスクトップ型を比較すると, ノート型のサイズ を規定しているのはキーボードのサイズといえる。一 つひとつのキーのサイズはノート型, デスクトップ型 ともほほ同じであるが, テンキーやファンクションキ 一の数が削られることにより利便性に影響している. また, キーボードの傾斜はフラットで手首, 上腕部へ の筋負担に考慮が必要であろう. 作業姿勢についても キーボードとディスプレイが分離できないため, 別項 に述べられているように作業姿勢にいくつかの問題点 が認められる.さらに，一般に我が国の狭いオフィス においては，デスクトップ型を設置するスペースが無 いゆえ, 日常用いている事務机を有効（?）利用する ために書類やファイルの山をかき分けてノート型で作 業している状況が散見できる。このような状況は本質 的な FPD のエルゴノミクス課題とはややかけ離れる が重要な要因といえる.また，市販価格は各社ともそ の機能などを勘案するとほほ同一であると考えてよく, これは技術的には可能な事象もコストとのトレードオ 
フによる販売戦略ゆえに製品として市場へ供給されに くいという背後要因が浮かび上がる.

\section{参考文献}

1）浜田 洋：人にやさしいVDT：使いやすいソ フトウェア, 人間工学, 31 巻, 特別号, 100 103, 1995.

\section{5. ノート型パソコン使用時の作業特性 とその人間工学的対策}

\section{愛知みずほ大学人間科学部 斎藤 真}

ノート型パソコン (以下 NPC) は, FPD の品質に由 来する視認性 ${ }^{1 \sim 3)}$ や画面とキーボードが一体化したこ とによる特有の作業姿勢(4) の問題など, 従来のデスク トップ型パソコン (以下 DPC) とは異なった人間工学 的対策が必要と思われる。筆者は，NPC と DPC 使用 時のオペレータの眼球運動, 作業姿勢および僧帽筋の 筋活動について比較検討を行ってきた（図 1 参照).

その結果 (表 1 参照), NPC 使用時の平均垂直眼位 は下方視となうたが, 視距離は著しく短くなる傾向が 示された。また頭部角度は, DPC 使用時よりも前傾 し, その変動は DPC と比較して少ないことが明らか となった。ささに僧帽筋の EMG は, NPC 使用時の筋 緊張が DPC 使用時よりも高く，頭部運動の少なさを 考慮すると, 静的筋負担が大きいものと考えられる.

これらのことから NPC 使用時の作業特性は, DPC 使用時のそれとは明らかに異なり, 従来の VDT 作業 ガイドラインなどを適応させるには困難な部分が多い ものと思われる．垂直眼位からみると NPC は有利で あるが5), 視距離の短さに起因する視覚系や著しく前 傾することによる筋骨格系への負担は DPCよりも大 きいことが推察された. 今後は, 下方への眼位と適度 な視距離を保ちながら, 筋骨格系への負担の少ない作 業姿勢を維持できるNPC の開発が課題と考える. 具 体的には画面とキーボードを分離し, 位置調整ができ る構造を推奨する. 現在市販されている NPC は, 画面 やキーボードの位置調整ができないものであり, 使用 に際しては各自の事務机やテーブルの上が主であるこ とから，早急に人間工学的対策を立てることを提案し たい.

\section{参考文献}

1）窪田 悟：平面ディスプレイの人間工学的要件, 照明学会誌, 76(10), 549〜556, 1991.

2）窪田 悟：液晶ディスプレイの視野角の評価,

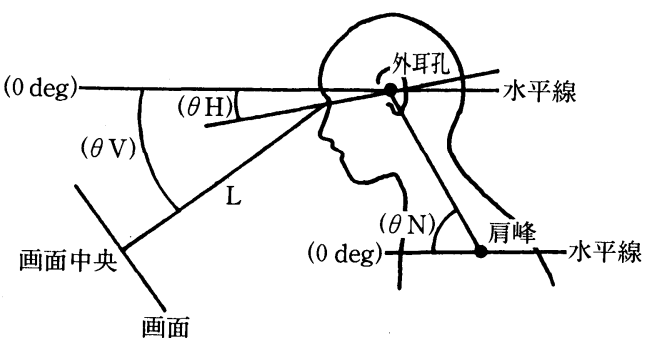

図 1 作業姿勢の計測対象とその定義

視距離 $\mathrm{L} ：$ 被験者の眼球から画面中央までを結ん だ線の長さ $(\mathrm{mm})$

視線角度 $\theta \mathrm{V}$ : 視距離 $\mathrm{L}$ と水平線のなす角度 (deg)

頭部角度 $\theta \mathrm{H}$ : リードライン（外眼角と外耳孔の 中心を結んだ線）が水平線となす 角度 (deg)

頝部角度 $\theta \mathrm{N}$ : 屃峰と耳孔を結んだ線が水平線 となす角度 $(\mathrm{deg})$

角度はいずれも水平線を $0 \mathrm{deg}$ とし, 時計回りを正, 反時計回りを負とした

表 1 NPC, DPC 使用時の視線角度, 視距離, 頭部角度, および頝部角度の平均値, 標準偏差 $(\mathrm{N}=10, * *$ ： $\mathrm{P}<0.01)$

\begin{tabular}{lrrrrr}
\hline & \multicolumn{3}{c}{$\mathrm{NPC}$} & \multicolumn{3}{c}{ DPC } & & \\
& MEAN & SD & MEAN & SD & \\
車直眼位 $\theta \mathrm{V}(\mathrm{deg})$ & -35.03 & 5.59 & 0.29 & 7.47 & $* *$ \\
視距離 $\mathrm{L}(\mathrm{mm})$ & 329.05 & 52.42 & 405.71 & 42.95 & $* *$ \\
頭部角度 $\theta \mathrm{H}(\mathrm{deg})$ & -21.97 & 10.04 & -5.59 & 15.72 & $* *$ \\
頝部角度 $\theta \mathrm{N}(\mathrm{deg})$ & 48.15 & 13.70 & 51.95 & 12.29 & \\
\hline
\end{tabular}

テレビジョン学会誌, 46(3), 354〜356, 1992.

3）吉武良治, 土屋和夫：STN 液晶ディスプレイ の見やすさに影響を与える要因の検討, 人間工学, 29(4), 209〜214, 1993.

4）斎藤 真：FPD ワークステーションの形態と 作業姿勢，人間工学， 31 (特別号)，120 123, 1995.

5) Sh. Saito, M. Sotoyama, S. Taptagaporn, T. Suzuki and S. Saito : Characteristics of vertical eye movements in the workstation used Flat Panel Display (FPD), Human-Computer Interaction 19A, 756 761, Elsevier Science Publishers, 1993. 


\section{6.フラットパネルディスプレイを使用 したヘッドマウントディスプレイの エルゴノミクス課題}

\section{産業医学総合研究所 外山みどり}

フラットパネルディスプレイ技術の進歩により実現 したヘッドマウントディスプレイ (HMD) は, 省スペ ース, 携帯性, 機密性などの点で優れており, 職場へ の導入が進むことが予想される.ここでは, VDT 作業 用に試作された HMD を試用した研究1)をもとに, HMD のエルゴノミクス課題について述べる.

今回試用した HMD は，ワードプロセッサに用いる ことを想定して開発されたものである. 頭部装着部は 約 $350 \mathrm{~g}$ であり，これをアームとパッドで頭部に固定 する。ディスプレイは一つで，これを左右どちらかの 眼で見る.ディスプレイはネガティブ表示（暗い背景 に明るい文字) の小型液晶パネル（縋 $2.0 \mathrm{~cm} *$ 横 2.7 $\mathrm{cm}$, 画素数 $640 * 480)$ であり, 視距離 $50 \mathrm{~cm}$ で 14 イ ンチの画像となるようレンズ系を設計してある，原稿 やキーボードはディスプレイと顔面の隙間から両眼で 見る. 文字はキーボードから入力する.

HMD では, ディスプレイを頭部に固定するので, 姿 勢の自由度は大きくなる. また, 外光が遮断されるの でグレアはなく, この点で眼への負担は小さくなると 考えられる. 閉ざされた空間で集中しやすい反面, 以 下のような負担が増すと考えられる。

(1) 眼への負担

HMD は頭部に装着されるため, ディスプレイと 眼との距離は固定される.したがって HMD 使用 時には, 見にくい文字や画像の細かい部分をはっ きり見ようとする際，画面に近づくことができず， 焦点調節のみに頼ることになり, 調節系への負担 が増す.また, HMD では頭部の動きがキャンセル され, 視線の移動は眼球運動のみに頼らねばなら ず，より大きな眼球運動が必要になり，これも眼 への負担を増すことになる。

(2) 筋骨格系への負担

小型, 軽量といえどもある重さを持った機器を頭 部に装着することにより, 頝, 肩などの筋骨格系 への負担は大きくなる.

技術の進歩により新たに生み出された機械や装置は, 生産性を高め作業の効率化を進めるのに役立つと同時 に, 人間工学上あるいは産業衛生上の問題を生み出す 可能性が常にある.HMD などの新たな機器を開発す
る際には, ヒトへの影響について十分検討を行う必要 がある。

\section{参考文献}

1）外山みどり, Villanueva, M.B.G., 城内 博, 丸 本達也, 斉藤 進：ヘッドマウントディスプレイ を利用した VDT 作業, Flat Panel Display の ューマンファクタシンポジウム, 12〜19, 1995.

\section{FPD エルゴノミクスの課題}

\section{沖電気工業株式会社 中野義彦}

マイクロエレクトロニクスを初めとする半導体技術 の進化は著しく, その半導体技術に支えられ, マイク ロコンピュータの技術発展・性能向上は目を見張るも のがある. マイクロコンピュータの高速化, 高性能化 とメモリの集積度向上・低価格化，ビデオ周辺の性能 向上や, 通信インフラの拡充, ソフトウェアの進展に より，パーソナルコンピュータの普及は我が国でも目 覚ましいものがある。

一方，LCD に代表される FPD は性能を向上させ, オフィスユースに十分使用可能となってきている. ま た, FPD の軽・薄・省エネを利用してモーバイルコン ピュータも増加傾向にある.「どこでも誰でもコンピュ ー夕」は，コンピュータ利用を便利と考える人々にと っては切望されており, 書き換え可能な紙すなわち,

○折り畺み可能で必要に応じて大きい画面や小さい画 面に任意にでき，

○省エネで,

携帯便利で,

○紙のように自由に書き込み消去ができ，

○ネットワークに接続でき（それも高速の無線のネッ トワーク),

○情報の取り出し，コミュニケーションが自由に図れ る,

のディスプレイ上に構成するキーボードも伸縮自在で ストロークや適切な触覚のフィードバックのある製 品(たとえば開けば A 3 サイズで, A 3 の領域を自由 にディスプレイとキーボードにアサインでき, スト ロークや適切な触覚のフィードバックのある, 現状 は実現されていない製品)

が理想と考えられる。

一方, 現状の FPD は様々な課題 (反射型では, 反射 輝度が低い, 入射光の角度や見込み角により輝度・コ ントラストが著しく変化する，鏡面反射が大きく鏡面 反射を避けるため画面の表面処理をマット加工したも 
のが多いが，映り込み光源の見込み角が増加するほど 鏡面反射率が高くなる，またマット加工により画像の 先鋭さがある程度犠牲になる……）を持っている．ま た, FPD が書き換え可能な紙として将来オフィスで普 及していくことを考慮すると，オフィスの照明環境， なかでも天井照明と水平に近く配置した FPD の関係 を考慮すると，反射防止を FPD だけに課してみても， 解決は困難でオフィスの照明条件にも言及していくべ きと思われる。

具体的に数值をあげれば，いわゆるVDT 照明とし て下面開放型でルーバ付きの照明が主流であるが，こ の照明方式は画面がほほ鉛直に配置される CRT ベー スの VDT に対しては顕著な効果があり，オフィスの 視環境を改善してきた。しかし水平に配置した FPD 画面に対しては, 映り込みが目立つ問題がある。ルー バ照明の下面から見上げた輝度は, $10000 \mathrm{~cd} / \mathrm{m}^{2}$ 程度 もある, FPD の鏡面反射率を $1 \%$ とすると鏡面反射輝 度は $100 \mathrm{~cd} / \mathrm{m}^{2}$ 程度になる. 発光輝度を $100 \mathrm{~cd} / \mathrm{m}^{2}$, 暗 地発光輝度を $10 \mathrm{~cd} / \mathrm{m}^{2}$ とするとコントラストは $210 /$ 110 すなわち 1.91 であり, 現在審議中の FPD エルゴ ノミクス規格原案 ISO CD 13406-2 で要求するコント ラスト 3 を満たせない.

さらに, 最近のアプリケーションは階調表示, 多色 表示も多用する.この場合は低い階調でも暗地に対し てコントラスト 3 を確保しなければならないわけで, 高輝度の鏡面反射があると適切な視認性が確保できな い.このような課題に対しても，エルゴノミクス研究
の成果を生かして, FPD がオフィスで快適に使用でき るように，またモーバイルコンピューティングの世界 でも快適に使用できる条件をエルゴノミクスの観点か ら求め, FPD ビジュアルエルゴノミクスの指針を提供 していくことが重要と考える.

\section{8.おわりに}

以上のように当該分野の専門家が, FPD エルゴノミ クスの今日的課題について，それぞれの立場からの考 えを述べた。はじめに記したように，日本人間工学会 では FPD 利用の人間工学ガイドライン検討委員会を 新しく設置した。発起人は, 阿久津正大 (玉川大学), 斎藤真 (愛知みずほ大学), 斉藤進 (産業医学総合研究 所), 外山みどり(産業医学総合研究所), 中野義彦 (沖 電気工業(秼), 畑田豊彦(東京工芸大学), 堀江良典 (日 本大学), 吉武良治（日本アイ・ビー・エム侏）の諸氏 である. 委員会では, FPD エルゴノミクスの現状につ いて調査を行うとともに，できるだけ早急に FPD 利 用の人間工学ガイドラインを作成し提案する計画であ る.この件に関するご提案やご意見のある方は，下記 の委員会委員長までご連絡いただければ幸いである。

干 214 神奈川県川崎市多摩区長尾 6-21-1 労働省 産業医学総合研究所 斉藤 進

TEL : 044-865-6111 FAX : 044-865-6116

E-mail : saitos@ niih.go.jp 